\title{
Sustainable development features of international business tourism
}

\author{
Elena Okhrimenko*, and Olga Ergunova \\ Ural State University of Economics, St. 8 March / Narodnaya Volya, 62/45, 620144 Yekaterinburg, \\ Russian Federation
}

\begin{abstract}
The authors have identified the features of the international business tourism development; analyzed the main business tourism segments. The authors provide the rationale that it is business tourism that has a huge impact on the level of income and the sustainability of economic development. Business tourism can be classified as a profitable and promising type of tourism. The authors consider the key factors influencing the development of international business tourism and the economy of the respective territory; the features of the MICE industry and its impact on business tourism. The characteristic features of international business tourism have been investigated and substantiated; the factors influencing the development of business tourism infrastructure in foreign countries have been identified. The authors conducted a study and a comparative analysis of the expenditure on organizing business tourism; revealed the specifics of the business tourism infrastructure in European countries; the authors studied and analyzed external business relations, increased business activity, the quality of business infrastructure at the regional level and their impact on the development of business tourism and the economy.
\end{abstract}

\section{Introduction}

In modern conditions, Russia continues to consider issues related to the development of foreign economic activity. In fact, it becomes important to reasonably approach the definition of a new course, taking into account the current situation in the world associated with the pandemic. It is necessary to continue to establish international relations not only in various spheres of the economy, but also with the largest possible number of countries that have appropriate business traditions with specific features. In this regard, it is important to further consider and establish business ties in the field of business tourism with the countries of near and far abroad.

International business tourism, on the one hand, contributes to stable, first of all, economic growth, on the other hand, the business tourism market may turn out to be less resistant to external factors, for example, climatic, political, social, etc.

In fact, it all depends on how deeply business partners study characteristic features of international business tourism. However, it is quite obvious that business tourism belongs to

\footnotetext{
* Corresponding author: oelenai@yandex.ru
} 
one of the profitable sectors of the economy, attracts large capital and has its own unique and distinctive features.

The business tourism market is not well known in the circles of tourism business specialists who are engaged in traditional mass destinations [1].

Business tourism undoubtedly occupies a leading place in the programs of economic development in many countries.

Despite the rather difficult situation in the world associated with the pandemic, there is still a special, increased interest in further study of the field of business tourism.

\section{Materials and Methods}

In connection with the above, it is important to focus on the works of scientists studying the field of tourism. General characteristics of business tourism are considered in the works of E. V. Pecheritsa [8] and M. A. Dybal [3]. The processes of globalization and their influence on the formation of the Russian business tourism market are identified and studied by A. Khakan [9], V. V. Evseev [4], E. A. Bikbulatova [2]. The main issues related to the prospects for the development of tourist and recreational clusters at the subregional level, taking into account regional spatial development, as well as improving the management of the development of a tourist and recreational cluster on the basis of the cluster approach, are discussed by E.N. Koroleva, M.V. Kournikova [6] and others.

"International business tourism (business tourism) is travel by company employees from one country (region) to other countries (regions) for business purposes, in other words, these are business trips. Such trips are associated with the performance of professional duties " [8, p. 733].

Moreover, business tourism can be carried out at any time of the year and can be classified from this point of view. As world experience shows, business tourism is quite resistant to the impact of political, economic, climatic and other factors. It is business tourism that has a huge impact on the level of income and the sustainability of economic development. Consequently, business tourism can be attributed to a profitable and promising type of tourism.

In addition, the development of international business tourism has an impact on the development of the economy of the respective territory. It involves not only stimulating the provision of services, but also increasing the growth of the volume of tourism services.

In business travel, the abbreviation MICE is used. One of the MICE criteria includes the specifics of the service, i.e. a specialized agency (mediator) not only organizes the event, but can also arrange for it. Here it is important to focus on the fact that the professional organizer deals independently with the content and direction of the program.

One of the important MICE criteria is to determine the direction of the service. It is important to understand that determining the focus of a service is at the intersection of protocol and internal PR campaign.

Service attributes are another important MICE criterion. MICE defines attributes such as mood creation, creativity, and personality.

In the structure of the MICE industry, meetings and seminars, conferences and congresses are of particular importance.

In the field of business travel, in addition to the MICE industry, the concept of business travel (BT) is quite common. The study of the essence of business travel makes it possible to study the processes taking place in the field of business travel in the most detailed way. Today there are two meanings of business travel:

- firstly, business travel is a journey, the purpose and location of which are set by the business, while all costs are reimbursed by the company [11]; 
- secondly, business travel is a journey with the goal of a commercial business, a government assignment or education that provides for recreation as a secondary motivation [11].

Thus, for business travel, business goals are a fundamental and key action, while travel goals are secondary.

According to research conducted around the world by the marketing company HorvatConsulting, business tourism occupies a leading position in terms of economic indicators in the field of tourism, which is reflected in Figure 1.

\section{Profitability level}

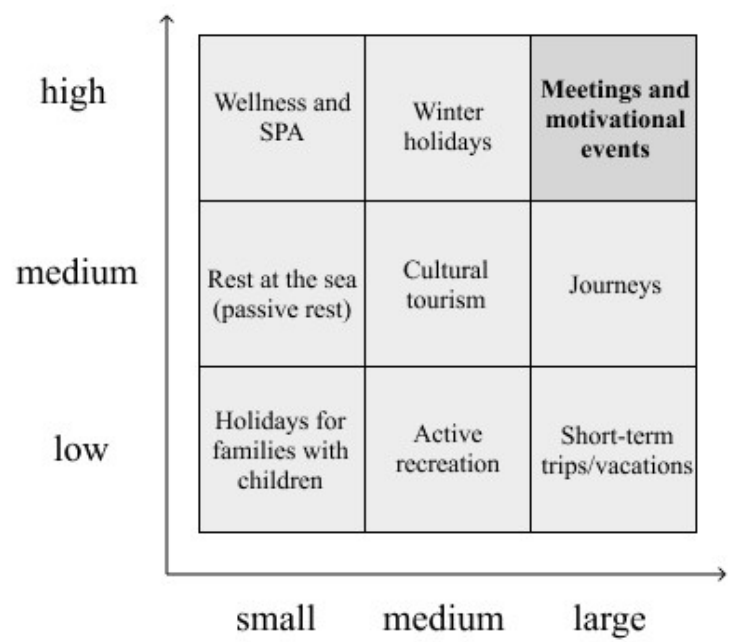

market size

Fig. 1. The tourism market structure by economic indicators [7, p. 96]

Where: Высокий - High; Средний- Average; Низкий - Low; Малый - Small; Большой - Large; Оздоровление и СПА - Wellness and SPA; Зимние каникулы - Winter holiday; Встречи и мотивационные мероприятия - Meetings and motivational activities; Отдых на море (пассивных отдых) - acation at sea (passive vacation); Культурный туризм - Cultural tourism; Путешествия Travels; Отдых для семей с детьми - Holidays for families with children; Активных отдых - Active rest; Краткосрочные поездки/отдых - Short term trips / vacations;

It is important to note that within the framework of the presented comparative characteristics, the share of expenses on business tourism is only $23 \%$, while other types of tourism account for $77 \%$ (Fig. 2).

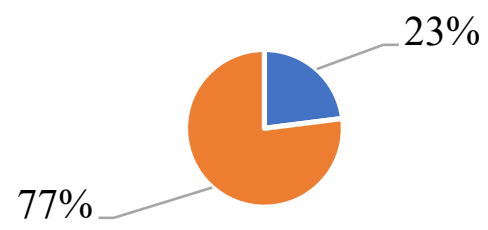

- Business tourism

- Other tourism types

Fig. 2. The share of expenses for organizing business tourism in the total expenses of the tourism industry in $2017, \%$ 
There is no doubt that business tourism has a positive effect on all areas of the economy. For example, an increase in sales in various brand and souvenir boutiques is facilitated by the fact that they are often located close to hotels, business centers, and congress halls. In addition, they contribute to an increase in a positive aspect of various services (transport, restaurant, etc.). Organizations holding various cultural events have an opportunity to increase their incomes.

Outbound travel costs by country are shown in Figure 3.

The figure shows that the representatives of China (19.1\%) have a low share of the costs of the world business tourism market, while Spain has the lowest share of $2.1 \%$. The share of Russia is close to that of Spain, exceeding it by only $0.3 \%$.

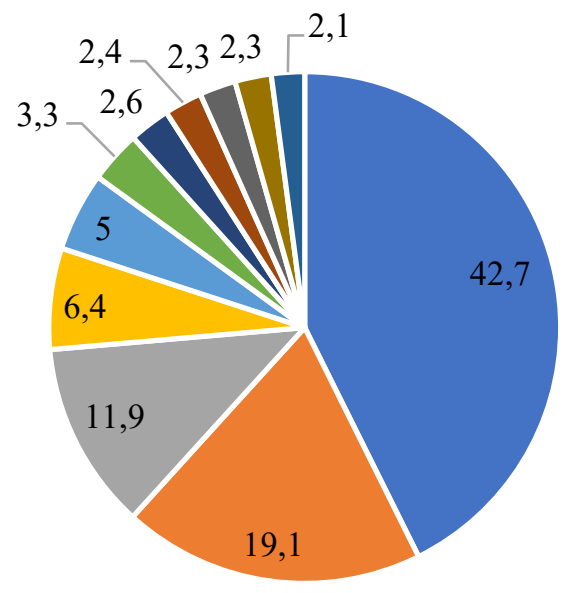

$$
\begin{aligned}
& \text { - Other countries } \\
& \text { - China } \\
& \text { - USA } \\
& \text { - Germany } \\
& \text { - Great Britain } \\
& \text { - France } \\
& \text { - Canada } \\
& \text { - Russia } \\
& \text { - Australia } \\
& \text { - Italy } \\
& \text { - Spain }
\end{aligned}
$$

Fig. 3. Expenses for outbound travel (business travel) by countries in 2017, \%

According to the latest data, Europe stood out for its expensive business tourism infrastructure due to the rise in the euro currency price. This aspect had a significant impact on the decline in demand within the tourism industry of the European Union.

It is obvious that business tourism and its development are greatly influenced by the development of business tourism infrastructure. In terms of the totality of these indicators, the current leaders of the business tourism market are the EU countries and the USA, and the countries of Southeast Asia are close to them. Despite the fact that Russia is not yet among the leaders of the business tourism market, nevertheless, it is strenuously making its way to the top, developing its business infrastructure.

Currently, Russia already has two cities in the top three cities for business and event tourism in the world (Moscow ranks first, St. Petersburg - third), the best business hotel in the world (Radisson Royal Moscow Hotel). In addition, Russia owns the best company in Europe, Aeroflot, and Sheremetyevo International Airport ranks second in the rating of the best airports in the world. In addition, the infrastructure of Sochi is actively developing, which, in terms of beauty and variety of natural landscapes, is not inferior to the resort cities of Southeast Asia.

It is important to note the fact that the international business tourism industry has a positive impact on the regions of our country.

Every year, the interest in Yekaterinburg from the world business community is increasing: in 2017, 165 business visits and 88 diplomatic visits took place [5].

The annual International Exhibition of Industry INNOPROM is one of the key elements in positioning Yekaterinburg as an all-Russian exhibition center. In 2017, more than 600 
companies from 20 countries took part in the exhibition, including representatives of the largest international companies Siempelkamp, Toyota Motor, Mitsubishi Motors, Yokogawa Electric, Toshiba, Fanuc Corporation, Siemens, Yamazaki Mazak Corporation, Volvo Trucks Corporation, SAP. The opening of the exhibition was attended by the President of the Russian Federation V.V. Putin [5].

In 2017, the number of representative offices of foreign companies, offices of official distributors and dealers in Yekaterinburg increased by two units and by the end of the year amounted to 360 units.

According to the Ural Customs Administration of the Federal Customs Service of the Russian Federation, since the beginning of 2017, the foreign trade turnover of the Sverdlovsk Region amounted to $\$ 10.6$ billion (the foreign trade balance is $\$ 3.2$ billion). The top ten countries-contractors of the Sverdlovsk region included the USA, China, Kazakhstan, Germany, Greece, Czech Republic, France, Iraq, Italy, Belarus.

The expansion of international relations and the establishment of business contacts with foreign countries is facilitated by the work of the consular corps accredited in Yekaterinburg. At the end of 2017, there were 24 accredited consular offices in the city. Yekaterinburg steadily retains its third place in the Russian Federation in terms of the number of consular missions and foreign diplomats. At the end of 2017, Yekaterinburg has 14 partner cities [5].

According to the Committee for External Relations of the Administration of the city of Yekaterinburg, in 2017 at least 410 congress events were held in Yekaterinburg, including 24 large ones (with more than 1000 participants). The total number of participants in the events increased in relation to the level of 2016 by 9.7 percent and amounted to 170 thousand people. The number of participants in major events amounted to 116.7 thousand people [5].

Thus, it can be stated that in recent years, external business relations have been actively developing in Yekaterinburg, business activity has been increasing, and the quality of the business infrastructure has been improving.

\section{Results and Discussion}

The analysis of the characteristic features of international business tourism presented in the study will allow a more detailed approach to identifying the specific features of the development of business tourism at the regional level. Moreover, taking into account the influence of environmental factors, it will enable to more clearly define and conduct a deep analysis of the strengths and weaknesses of the state of the tourism sector in the regions in order to strengthen their positions and increase their attractiveness in the international business tourism market.

Thus, all the designated aspects will contribute to further cooperation in various ties, namely business, scientific, cultural, economic with the countries of near and far abroad.

\section{Conclusions}

As a result of the study, it is possible to present conclusions within the framework of the analysis of the characteristic features of international business tourism, which will allow:

- to approach in more detail the identification and definition of the strengths of business tourism in the regions;

- to strengthen the positions of Russian companies in the business tourism market with minimal costs;

- explore the specifics of strategic planning within the tourism service sector with the aim of a well-grounded approach to positioning services in the international arena; 
- increase the attractiveness of business tourism in the regions in order to attract investments for further development.

At the same time, the development of any territory, any market segment is impossible without competent strategic planning, with account of the existing specifics of the business market of the regions and the country as a whole. It is necessary to investigate not only the specifics of strategic planning, but also the characteristic features of organization and management in the field of international business tourism in more depth and in detail.

\section{References}

1. A.Y. Alexandrov, International tourism, 221 (2010)

2. E. A. Bikbulatov, Yu. V. Dmitry, T. L. Bazhenova, International Scientific Journal Innovation Science, 5, 88 (2017)

3. M. A. Dybal, Innovative Technologies in the Service: Collection of Materials of the IV International Scientific and Practical Conference (18-19 December 2014), 287 (2015)

4. V. V. Evseev, D. V. Kharitonov, Scientific and Analytical Journal Observer - Observer, 2(325), 17 (2017)

5. Results of socio-economic development of the municipality "City of Yekaterinburg" in 2017/Department of Economy Administration of the city of YekaterinburgYekaterinburg, 156 (2018)

6. E.N. Korolev, M.V. Kournikova, Materials of the first International Volga Conference on Economics, Humanities and Sports (FICEHS 2019) (2019)

7. N. N. Morozova, Bulletin of the Don State Technical University, 12-3(64), 94 (2012)

8. E.V. Pecheritsa, Modern management technologies - 2014: Collection of materials from the international scientific conference, 733 (2014)

9. А. Hakan, ИноСМИ.py, https://inosmi.ru/

10. Travel \& Tourism : Global Economic Impact \& Issues 2018. - London (UK): WTTC, 12 (2018)

11. Glossary of tourism terms, http://www.uniquelytexas.org/ 